\title{
Alkaloid levels of a tall larkspur species in southwestern Alberta
}

\author{
W. MAJAK, R.E. MCDIARMID, J.W. HALL, AND W. WILLMS
}

Authors are toxic plant biochemist and research technician, Agriculture and Agri-Food Canada (AAFC), Range Research Unit, Kamloops, B.C. V2B 8A9; statistician, $A A F C$, Summerland, B.C. VOH 1ZO; and range ecologist, AAFC, Lethbridge, AB T1J $4 B 1$.

\begin{abstract}
Tall larkspurs (Delphinium spp.) are widely distributed in western North America and they kill more cattle on rangelands than any other poisonous plant. In Alberta, Canada, D. brownii Rydb. has a long history of causing cattle poisoning. The neurotoxic norditerpenoid alkaloid methyllycaconitine (MLA) was first detected in D. brownii over 50 years ago. A 2-year (1996 to 1997) survey was conducted on the levels of MLA in D. brownii collected at 5 sites in the foothills of southwestern Alberta. The vegetative stage of growth yielded the highest levels of MLA and the decline and change in concentration during that interval could be predicted on the basis of Julian day alone. The MLA levels during bud to pod development were not significantly different but they exceeded the reported levels for MLA in low larkspur by 5to 10-fold. A new method is described for the determination of MLA by HPLC.
\end{abstract}

Key Words: Poisonous plants, Delphinium brownii, neurotoxic alkaloids, methyllycaconitine

Larkspur (Delphinium spp.), especially the tall larkspurs, constitute the most serious poisonous plant problem to rangeland cattle in North America (Nielson and Ralphs 1998, Wroe and Smith 1991, Fowler et al. 1982). Four species of tall larkspur predominate in western USA: D. barbeyi Huth, D. glaucescens Rydb., D. occidentale S. Wats., and D. glaucum S. Wats. (Ralphs et al. 1997). A large geographically separate population of D. glaucum also occurs in northwestern Saskatchewan (SK) and Alberta (AB), extending through northern British Columbia (B.C.), the Yukon, Western Mackenzie and Alaska (Brayshaw 1989). The 2 populations of D. glaucum are sometimes treated as distinct species (Hitchcock and Cronquist 1964). The population in the Pacific States is referred to as D. glaucum (mountain larkspur) and that in Alaska and Canada as D. brownii Rydb. (tall delphinium). According to Brayshaw (1989), the morphological features that separate them on a taxonomic basis are minor and indistinct and he does not treat them as separate species and all modern Floras of Alaska, Yukon, Northwest Territories, B.C., $\mathrm{AB}, \mathrm{SK}$ agree. However, the chemical literature on tall larkspur in Canada always refers to D. brownii, so we have chosen to retain the 2 species concept.

The authors would like to thank Michael Benn, Garry Manners and Dale Gardner for providing alkaloid standards, Harriet Douwes for collecting plant samples, and Blair Surridge for technical assistance. This manuscript is dedicated to the late Dr. Robert T. Ogilvie for his contributions to the study of poisonous plants in Western Canada.

Manuscript accepted 30 May 1999.

\section{Resumen}

"Tall larkspurs" (Delphinium spp.) están ampliamente distribuidas en el oeste de Norte américa, y ellas matan mas ganado en los pastizales que ningún otra especie de planta tóxica. En Alberta, Canadá, $D$. brownii tiene un largo historial como causante de la muerte de ganado por envenenamiento. El alcaloide neurotóxico norditerpenoide metilicaconitina (MLA) fue detectado por primera vez en $D$. brownii hace 50 años. Se condujo un examen de dos años (1996 a 1997) de los niveles de MLA en $D$. brownii colectado en 5 sitios al pie de las montañas del sudoeste de Alberta. Los más altos niveles de MLA se registraron cuando la planta estaba en la etapa vegetativa de crecimiento y la disminución y cambio en la concentración durante ese intervalo pudieron ser predichas en base solo a los días julianos. Los niveles de MLA durante el desarrollo de yemas y vainas no fueron significativamente diferentes, pero ellos excedieron entre 5 y 10 veces los valores de MLA reportados en "Low larkspur". Se describe un nuevo método para la determinación de MLA por medio de HPLC.

The detection of methyllycaconitine (MLA) in D. brownii occurred over 50 years ago (Manske 1938, Marion and Manske 1946). The proof of structure (Benn et al. 1963), the precise stereochemistry (Pelletier et al. 1981, Edwards and Przyblyska 1982) and the mode of action of the alkaloid (Aiyar et al. 1979, Nation et al. 1982) were subsequently elucidated. It is now well established that MLA is the principal neurotoxic alkaloid in most native species of Delphinium in North America (Manners et al. 1991, 1993, Majak 1993). The objectives of this study were 1) to develop a new method for MLA determination by HPLC since earlier column packings for MLA determinations on HPLC (Manners and Pfister 1993, Majak et al. 1987) were not readily available and 2) to compare MLA levels in D. brownii at different stages of growth and at different sampling sites in southwestern Alberta where cattle losses due to the ingestion of D. brownii can be severe.

\section{Materials and Methods}

The 5 sampling sites were located between Bow Crow Forest $\left(49^{\circ} 51^{\prime} \mathrm{N}, 114^{\circ} 0^{\prime} \mathrm{W}\right)$ and the $\mathrm{OH}$ Ranch $\left(50^{\circ} 35^{\prime} \mathrm{N}, 114^{\circ} 21^{\prime} \mathrm{W}\right)$ in the fescue (Festuca campestris Rydb.)-aspen (Populus tremu loides Michx.) parkland of southwestern Alberta, commonly known as the foothills. The elevations at the sites ranged from 1,400 to $1,600 \mathrm{~m}$ and the soils were loamy and characterized as Dark Gray Chernozem (Boralfic Boroll). 
Composite samples of D. brownii (100-200 g fresh weight, aerial portions) representing sequential stages of growth (vegetative, bud, flower, and pod) were collected randomly at each site during 2 growing seasons $(\mathrm{n}=26$ in 1996 and $\mathrm{n}=$ 31 in 1997). The number of samples at each stage of growth varied with site and year, depending on the duration of the phenological stage. When the larkspur plants became elongated and stemmy, the upper $50 \mathrm{~cm}$ of the shoot containing most of the leaves and the inflorescence was excised for analysis. The samples were freeze-dried, the alkaloids were extracted as described previously (Majak et al. 1987) and the extracts analyzed by HPLC utilizing a polymeric reverse phase column (PRP-1, 150 x $4.1 \mathrm{~mm}$, Hamilton Co., part no. 79444) and acetonitrile $0.1 \%$ phosphoric acid, 23:77, as the isocratic developing solvent at a flow rate of $1.8 \mathrm{ml} / \mathrm{min}$ with UV detection at $212 \mathrm{~nm}$. The PRP-1 column minimized tailing of alkaloidal compounds without the use of ion-pairing reagents (Majak et al. 1987), which can accumulate as residues and affect instrument performance. The alkaloid was quantified by the external standard method with duplicate injections per plant sample using a $20 \mu 1$ sample loop.

The effects of site and stage of growth on MLA concentration (\% by weight) were determined by analysis of variance, or co-variance using the procedures of the SAS Institute Inc. (1989). Years were considered a form of replication. The data were transformed to logarithms for analysis to provide homogeneity of variance. Concentrations varied with collection date during the vegetative stage but not during the bud, bloom, or pod stages. For this reason, the data from the vegetative stage were analysed separately from the data for the other 3 stages. For the vegetative stage, the sources of variation in the analysis of co-variance were site, year, site $\mathrm{x}$ year, Julian day (co-variate) and the residual error. A test for non-parallelism at different sites and years was also carried out. For the bud, bloom, and pod data, the sources of variation in the analysis of variance were stage, site, stage $\mathrm{x}$ site, year, year $\mathrm{x}$ site $\mathrm{x}$ stage (experimental error, includes year $\mathrm{x}$ site and year $\mathrm{x}$ stage) and the residual error. Least squares estimates of $\log$ (MLA) concentration were made for each stage, site and year and back transformed for presentation. As is appropriate for back transformed logarithmic data, the variability was indicated by the coefficient of variation of the mean. This is the standard error divided by the mean and expressed as a percentage.

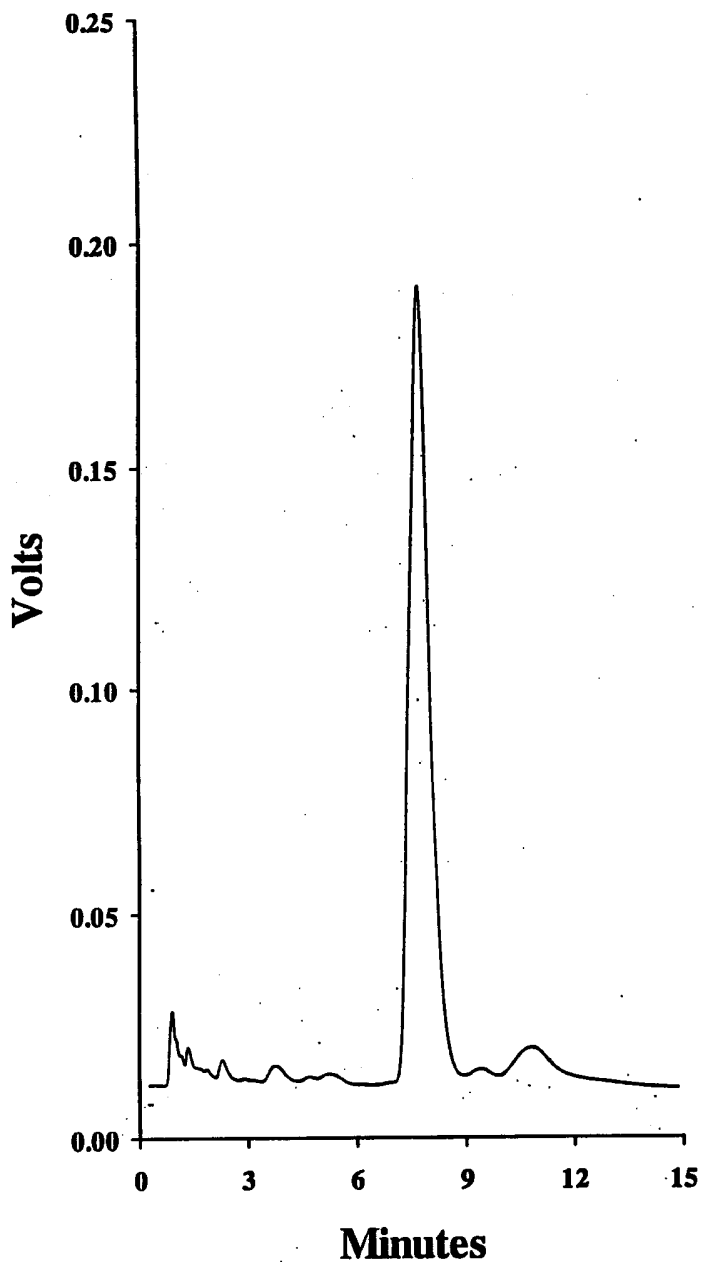

Fig. 1. HPLC separation of MLA $(320 \mathrm{ppm})$ from a purified extract of freeze-dried $D$. brownii (0.5 g). Column: Hamilton PRP-1 (150 x $4.1 \mathrm{~mm})$. Detection: $212 \mathrm{~nm}$. Mobile phase: acetonitrile $-0.1 \%$ phosphoric acid (23:77).

\section{Results and Discussion}

The detection limit for MLA on the PRP-1 column was $<10$ ppm and the resolution on HPLC was equal to that described previously (Majak et al. 1987). For example, MLA (retention time $=7.4$ min) was separated from nudicauline (retention time $=8.6 \mathrm{~min}$ ) with near baseline resolution. Nudicauline differs from MLA only at $\mathrm{C}_{14}$ where MLA has a methoxy group and nudicauline has an acetyl group. In agreement with earlier studies (Benn et al. 1963) and as evidenced by the single peak on HPLC (Fig. 1), MLA was the major anthranoyl-type norditerpenoid alkaloid thus far detected in $D$. brownii. It is possible that geyerline and grandiflorine, previously reported in D. glaucum (Manners et al. 1998) were also present in D. brownii but only in trace quantities. These alkaloids were also resolved in our HPLC system.
The norditerpenoid alkaloids, browniine (Benn et al. 1963) and browniine acetate (Aiyar et al. 1978) have also been isolated from $D$. brownii, but these alkaloids would not be visualized by UV detection on HPLC owing to the absence of the anthranoyl-group. The absence of this group also renders these alkaloids much less toxic than MLA (Benn and Jacyno 1983, Manners et al. 1993). Ralphs et al. (1997) reported on the concentration of total toxic anthranoyl-type norditerpenoid alkaloids in D. glaucum (mountain larkspur) but they did not specify on the proportion of MLA. They concluded however, that of the 4 species of tall larkspur that were examined in the USA, D. glaucum had the highest levels of toxic norditerpenoid alkaloids: $1 \%$ on a dry matter basis with the range extending from 0.5 to $2 \%$.

The highest levels of MLA in D. brownii occurred during the vegetative stage of growth and the levels extended from 1 to $5 \%$. These MLA levels were at least 2- to 
Table 1. Levels of MLA (\% by weight) in tall larkspur averaged for each stage, site, and year.

\begin{tabular}{|c|c|c|c|c|c|c|c|c|c|c|c|c|}
\hline \multicolumn{4}{|c|}{ Stage } & \multicolumn{6}{|c|}{ Site } & \multicolumn{3}{|c|}{ Year } \\
\hline Bud & Bloom & Pod & $\mathrm{CV}^{1}$ & 1 & 2 & 3 & 4 & 5 & $\mathrm{CV}$ & 1996 & 1997 & $\mathrm{CV}$ \\
\hline
\end{tabular}

10-fold greater than those reported for low larkspur (D. nuttallianum) at the same stage of growth (Majak 1993). This may well account for the much higher incidence of larkspur poisoning in the foothills of Alberta than in the southern interior of B.C. where low larkspur is widespread but tall larkspur is absent. Tall larkspur is also seasonally persistent as compared to low larkspur, which is seasonally ephemeral. Field observations on grazing cattle in Canada suggest that the larkspurs are a preferred species during the vegetative stages of growth (Majak and Engelsjord 1988, B. Maynard, personal communication, $\mathrm{OH}$ Ranch).

During the vegetative stage, there was a significant $(\mathrm{P}<0.0001)$ decline in MLA levels with time. The relationship between log concentration of MLA and time (Julian days after January 1) during the vegetative stage of D. brownii could be expressed as:

$$
\ln [\mathrm{MLA}]=6.1059-0.0310 \text { (days) (1) }
$$

where $\mathrm{r}^{2}=0.79, \mathrm{SE}$ (intercept) $=0.5824$ and SE (regression coefficient) = 0.003465. During 1996 and 1997, the vegetative stage in $D$. brownii began at the end of May and ended during the beginning of July. The rate of decline was the same for all sites and years (no significant non-parallelism). On average, the MLA concentration declined by about $3 \%$ of its value each day. There were no significant differences in the intercepts among sites or among years.

During bud, bloom, and pod development, there were no significant differences in MLA levels among stages of growth or among sites at those stages but average values for MLA were higher in 1997 than in 1996 (Table 1). The levels of MLA in D. brownii at the more advanced stages of growth were still 5- to 10-fold higher than those reported for low larkspur (Majak 1993, Pfister and Gardner 1998). This again underlines the much greater toxicity of this species of tall larkspur.

The rainfall in the study area during July and August, 1996, which was the bud to pod growing period, was 5 to $10 \%$ of normal. The rainfall for the same period in 1997 was closer to normal. Whether this difference in moisture affected the MLA levels in D. brownii is not known. There are only a few reports on the effect of moisture stress on tall larkspur toxicity and they are inconsistent. Olsen et al. (1990), using a mouse bioassay, reported no difference in the toxicity of D. occiden tale collected from a moist site and a dry site. Ralphs et al. (1997) compared toxic alkaloid levels in tall larkspur growing in shaded and unshaded areas. The alkaloid levels in $D$. barbeyi were higher $(\mathrm{P}<0.02)$ at the open site but significant differences were not detected in the alkaloid levels of D. occidentale from the 2 types of sites. In low larkspur, a seasonally ephemeral species, lower levels of MLA were associated with site conditions that reduced soil moisture stress (Majak et al. 1999). It is possible that moisture conditions affect alkaloids in climax species, such as tall larkspur, differently and more studies are required to resolve this issue.

In summary, a reliable method was developed for the analysis of MLA in $D$. brownii by HPLC. The vegetative stage of growth yielded the highest levels of MLA and the change and decline in concentration during that period could be predicted from Julian day alone. The MLA levels during bud to pod development did not show significant changes, nor were there differences in MLA levels among sites. The MLA levels in D. brownii, a tall larkspur, can be 5-to 10-fold higher than in $D$. nuttallianum, a low larkspur, and this may account for the much higher incidence of cattle poisoning from tall larkspur than from low larkspur ingestion in Western Canada.

\section{Literature Cited}

Aiyar, V.N., M. Benn, Y.Y. Huang, J.M. Jacyno, and A.J. Jones. 1978. The alkaloids of Delphinium brownii. Phytochemistry 17:1453-1454.

Aiyar, V.N., M.H. Benn, T. Hanna, J. Jacyno, S.H. Roth, and J.L. Wilkens. 1979. The principal toxin of Delphinium brownii Rydb., and its mode of action. Experientia 35:1367-1368.
Benn, M.H. and J.M. Jacyno. 1983. The toxicology and pharmacology of diterpenoid alkaloids. In S.W. Pelletier (ed.) Alkaloids: Chemical and biological perspectives. Vol. 1. John Wiley and Sons Inc., New York, N.Y.

Benn, M.H., M.A.M. Cameron, and O.E. Edwards. 1963. The alkaloids of Delphinium brownii Rydb. The structure of browniine. Can. J. Chem. 41:477- 482.

Brayshaw, T.C. 1989. Buttercups, waterlillies and their relatives in British Columbia. Royal British Columbia Museum, Victoria, B.C.

Edwards, O.E. and M. Przybylska. 1982. The lycoctonine family of alkaloids: a stereochemical revision. Can. J. Chem. 60:2661-2667.

Fowler, M., A.L. Craigmill, B.B. Norman, and $P$. Michelsen. 1982. Livestock Poisoning Plants of California. Leaflet 21268. Division of Agric. Sci. Univ. of Calif., Davis, Calif. 23 p.

Hitchcock, C.L. and A. Cronquist. 1964. Vascular Plants of the Pacific Northwest. Part 2: Salicaceae to Saxifragaceae. University of Wash. Press, Seattle, Wash.

Majak, W. 1993. Alkaloid levels in a species of low larkspur and their stability in rumen fluid. J. Range Manage. 46:100-104.

Majak, W. and M. Engelsjord. 1988. Levels of a neurotoxic alkaloid in a species of low larkspur. J. Range Manage. 41:224-226.

Majak, W., R.E. McDiarmid, and M.H. Benn. 1987. Isolation and HPLC determination of methyllycaconitine in a species of low larkspur (Delphinium nuttallianum). J. Agr. Food Chem. 35:800-803.

Majak, W., A.L. van Ryswyk, and J.W. Hall. 1999. Soil moisture influences low larkspur and death camas alkaloid levels. J. Range Manage. 52:127-131.

Manners, G.D., J.A. Pfister, M.H. Ralphs, K.E. Panter, and J.D. Olsen. 1991. Larkspur chemistry: toxic alkaloids in tall larkspurs. J. Range Manage. 45:63-67.

Manners, G.D., K.E. Panter, J.A. Pfister, J.H. Ralphs, and L.F. James. 1998. The characterization and structure-activity evaluation of toxic norditerpenoid alkaloids from two Delphinium species. J. Nat. Prod. 61:1086-1089.

Manners, G.D. and J.A. Pfister. 1993. Normal phase liquid chromatographic analysis of toxic norditerpenoid alkaloids. Phytochem. Anal. 4:14-18. 
Manners, G.D., K.E. Panter, M.H. Ralphs, J.A. Pfister, J.D. Olsen, and L.F. James. 1993. Toxicity and chemical phenology of norditerpenoid alkaloids in the tall larkspurs. J. Agr. Food Chem. 41: 96-100.

Manske, R.H.F. 1938. An alkaloid from Delphinium brownii Rydb. Can. J. Res. B. 16:57-60.

Marion, L. and R.H.F. Manske. 1946. Identity of the hydrolytic base obtained from Delphinium brownii Rydb. with lycoctonine. Can. J. Research B. 24:1- 4.

Nation, P.N., M.H. Benn, S.H. Roth, and J.L. Wilkens. 1982. Clinical signs and studies of the site of action of purified larkspur alkaloid, methyllycaconitine, administered parenterally to calves. Can. Vet. J. 23:264-266.
Nielsen, D.B. and M.H. Ralphs. 1988. Larkspur: economic considerations, $\mathrm{p}$. 119-129. In L.F. James, M.H. Ralphs, and D.B. Nielsen (eds.) The ecology and economic impact of poisonous plants on livestock production. Westview Press, Boulder, Colo.

Olsen, J.D., G.D. Manners, and S.W. Pelletier. 1990. Poisonous properties of larkspur (Delphinium spp.). Collect. Bot. (Barcelona) 19:141-151.

Pelletier, S.W., N.W. Mody, K.I.Varughese, J.A. Maddry, and H.K. Desai. 1981. Structure revision of 37 lycoctonine-related alkaloids. J. Amer. Chem. Soc. 103:6536-6538.
Pfister, J.A. and D.R. Gardner. 1999. Consumption of low larkspur (Delphinium nuttallianum) by cattle. J. Range Manage. (in press).

Ralphs, M.H., G.D. Manners, J.A. Pfister, D.R. Gardner, and L.F. James. 1997. Toxic alkaloid concentration in tall larkspur species in the western U.S. J. Range Manage. 50:497-502.

SAS Institute Inc. 1989. SAS/STAT users guide. (Version 6). 4th ed. SAS Inst. Inc., Cary, N.C.

Wroe, B. and R. Smith. 1991. Poisonous plants on range and pasture. Agri-fax. Alberta Agr., Edmonton, AB. 3 p. 